\title{
Characterization of adobe bricks used in developing countries: Mexico as a case of study
}

\section{Caracterización de ladrillos de adobe usados en países en desarrollo: México como caso de estudio}

\author{
GUTIÉRREZ-VILLALOBOS, José Marcelino †*, MORENO-MARTÍNEZ, Jatziri Yunuén, \\ CATALÁN-QUIROZ, Policarpo and GALVÁN-CHÁVEZ, Arturo
}

Universidad de Guanajuato Campus Celaya-Salvatierra, Av. Javier Barros Sierra 201 Col. Ejido de Santa María del Refugio C.P. 38140 Celaya, Gto. México

Instituto de Ingeniería, UNAM, Ciudad Universitaria, Delegación Coyoacán, C.P. 04510 Ciudad de México, México

ID $1^{\text {st }}$ Author: José Marcelino, Gutiérrez-Villalobos / ORC ID: 0000-0001-5947-1489, Research ID Thomson: S-76662018, CVU CONACYT ID: 173461

ID $1^{\text {st }}$ Co-author: Jatziri Yunuén, Moreno-Martínez / ORC ID: 0000-0002-6798-2067, Research ID Thomson: S-84412018, CVU CONACYT ID: 237707

ID $2^{\text {nd }}$ Co-author: Policarpo, Catalán-Quiroz / ORC ID: 0000-0002-2745-805X, CVU CONACYT ID: 350569

ID $3^{\text {rd }}$ Co-author: Arturo, Galván-Chávez / ORC ID: 0000-0002-3374-0481, Research ID Thomson: S-8432-2018, CVU CONACYT ID: 237706

DOI: $10.35429 / J A D .2021 .13 .5 .1 .12$

Received March 21, 2021; Accepted June 15, 2021

Abstract

In Mexico adobe masonry is a traditional building material common in rural areas with low economic development and a high degree of marginalization. In addition, a growing interest in adobe masonry is noticed in two ways: for rescuing the heritage and as a rediscovered environmentally friendly building material. The problems are found of how to carry out the conservation works of the great built heritage with this material, as well as the lack of skilled people at all levels, from designer to masons, because it is a forgotten technique. Hence, some recent investigations about the obtention of adobe mechanical properties and characterization of adobe bricks, including earth blocks, have been performed. This article investigates experimentally destructive and nondestructive tests used for this purpose, especially elastic mechanical properties, considering new sensors, systems and different techniques has led to the inspection of adobe bricks. The results show, compared destructive with nondestructive methods, a good correlation between both techniques. This study contributes towards a better understanding of the elastic mechanical properties of adobe bricks built in Mexico, considered as a developing country.

\begin{abstract}
Resumen
En México, la mampostería de adobe es un material de construcción tradicional, común en áreas rurales con bajo desarrollo económico y alto de grado de marginación. Además, un interés creciente en la mampostería de adobe se ha desarrollado de dos maneras: como rescate de patrimonios y como redescubrimiento de un material de construcción amigable con el ambiente. La problemática se encuentra en cómo llevar a cabo trabajos de conservación en construcciones consideradas como patrimonios construidos con este material, así como la falta de personal capacitado en todos los niveles, desde el diseñador hasta los albañiles, por ser una técnica olvidada. Debido a esto se han realizado algunas investigaciones recientes sobre la obtención de propiedades mecánicas del adobe y la caracterización de ladrillos de adobe, incluidos los de tierra. Este artículo investiga experimentalmente ensayes destructivos y no destructivos utilizados para tal fin, especialmente para obtener las propiedades mecánicas elásticas, considerando nuevos sensores, sistemas y diferentes técnicas que se han llevado para la inspección de ladrillos de adobe. Los resultados obtenidos de la comparación entre métodos destructivos y no destructivos muestran una buena correlación entre ambas técnicas. Este estudio contribuye a una mejor comprensión de las propiedades mecánicas elásticas de los ladrillos de adobe construidos en México, considerado como un país en desarrollo.
\end{abstract}

Mampostería de adobe, Ensayes destructivos, Ensayes no destructivos

\footnotetext{
*Correspondence to Author (e-mail: jmgutierrez@ugto.mx)
}

$\dagger$ Researcher contributing as first author. 


\section{Introduction}

The lack of territorial planning due to the disorderly growth of the population and the migratory flow generates a problem in the basic services for the integral development of a family. Housing is one of the human needs of great concern, one of the reasons why many people do not build their homes with industrialized materials that provide good structural security such as concrete, brick masonry and steel is due to the lack of economic resources. According to the CONEVAL (2015) the population living in poverty in Mexico was 55.3 million people. At the same time, the population in extreme poverty was 11.4 million people, which is equivalent to $44 \%$, and $9 \%$ respectively of the total population of the country. (CONEVAL, 2015).

An alternative in the construction of a house is a building process with an adobe masonry that despite being traditional is considered a symbol of poverty. However, in several states of the country, programs for the construction of adobe houses have been implemented with the purpose of achieving decent housing in the social context.

Adobe housing is a traditional type of construction in many developing countries due to that the materials used in adobe houses are earth, straw (Salazar-Hernández, et al., 2021), and water for the walls, with wood in the roof system, all items that are found in the local environment, making construction feasible. In Mexico, first, earth is excavated from an area near the place of construction.

That earth is then combined with straw and water until a uniform and malleable mixture is obtained. Finally, the mixture is placed in wooden molds to create the pieces of adobe, these are allowed to dry in the open air for approximately 30 to 60 days. Adobe has several disadvantages when compared to materials such as clay brick masonry and concrete. For example, adobe has low resistance to bending, shearing and axial compression forces (Bassoud et al., 2021; De Filippi et al., 2021). In addition, adobe degrades physically from the weathering to which it is exposed during its useful life.
Adobe houses built in Mexico are onestory dwellings (Figure 1). The rectangular floor plans have average areas of 30 to $50 \mathrm{~m}^{2}$, the longitudinal walls are 2.4 to $2.7 \mathrm{~m}$ high and the transverse walls are 3.0 to $3.9 \mathrm{~m}$ high. Wall thickness is typically 28 to $35 \mathrm{~cm}$. Adobe houses do not usually have intermediate dividing walls (Figure 1). They have one or two access doors, located on the longitudinal walls, 0.7 to $1.2 \mathrm{~m}$ wide and approximately $2 \mathrm{~m}$ high. Typically, there is a 0.3 to $1 \mathrm{~m}^{2}$ window on a longitudinal wall. Wooden lintels, 3 to $5 \mathrm{~cm}$ thick with supports approximately 20 to $30 \mathrm{~cm}$ long, are placed on the doors and the windows.
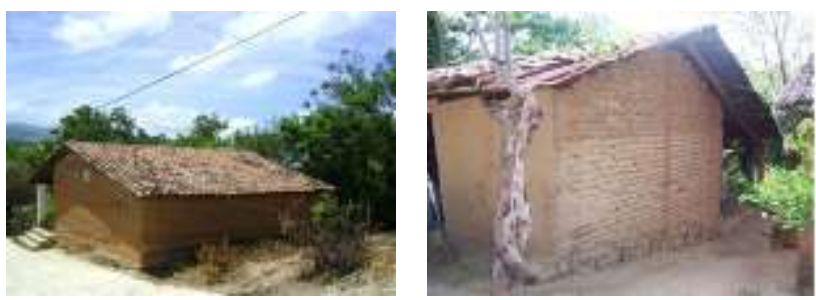

Figure 1 Typical adobe houses in Mexico Self-Authorship

The pieces of adobe are joined with a mortar composed of soil, water and dry grass to form a sludge; the joints are approximately 2.5 to $3.5 \mathrm{~cm}$ thick. The foundation is usually constructed of basalt masonry and the same mortar that is used for the pieces of adobe. The foundation starts 60 to $80 \mathrm{~cm}$ beneath the surface and continues up to 30 to $40 \mathrm{~cm}$ above the ground to avoid weathering of the bottom of the adobe walls (Arroyo, 2010).

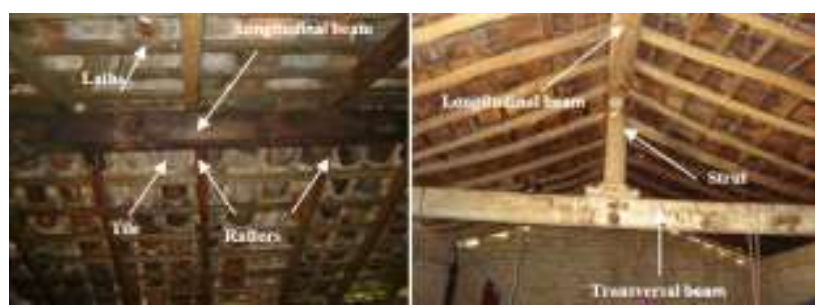

Figure 2 Roof system in adobe houses Self-authorship

The roof system (Figure 2) is either flat or pitched at an inclination anywhere from 15 to 30 degrees. The roof cover is fabricated from annealed clay tile mounted on a robust longitudinal wooden beam that rests on the transverse walls (head walls) and on two wooden struts; the latter are connected to a transverse beam, equally spaced, and resting on the longitudinal walls. 
Wooden rafters, also known as "madrinas" or battens, are placed approximately $60 \mathrm{~cm}$ apart on the walls and longitudinal beam rest. Transversing the rafters, wooden laths are placed every $25 \mathrm{~cm}$ to support the annealed clay tiles (Figure 2).

For the fabrication of adobe bricks, the mixture of the materials is done by hand, it is the materials (Figure 3a) and auxiliaries with a hoe, as a result a more uniform and malleable mixture is obtained. To this was added more water for use in wooden molds (Figure 3b).

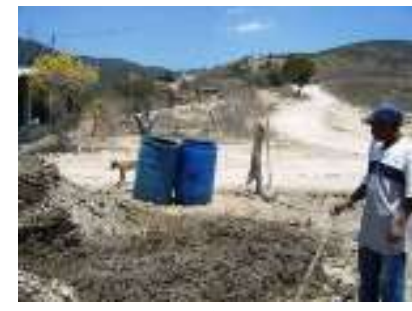

a)

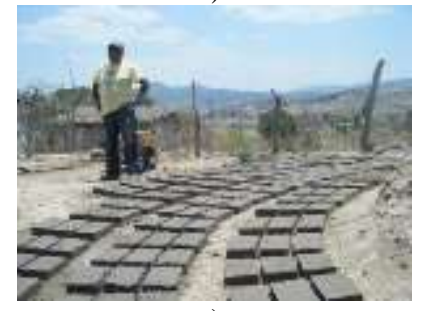

c)

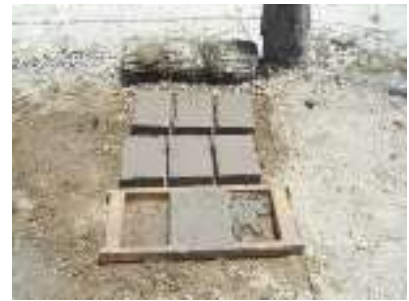

b)

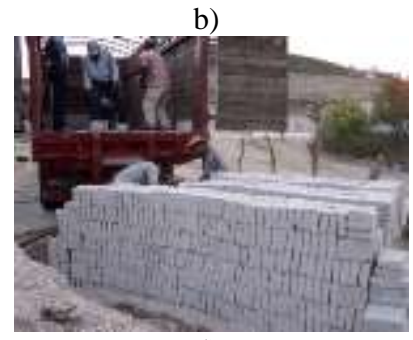

d)
Figure 3 Fabrication and transportation of adobe bricks: a) mixture of materials; b) wooden molds; c) adobe bricks are dried under the sun; d) Transportation of adobe bricks. Self-authorship

The mold is well filled, it is compacted with the fists until it is sure that there are no air spaces. It is recommended to pair with a metal or wood ruler the wooden molds for the adobes, following the traditional procedure for the elaboration of the pieces. We let it stay in water for a day so that it absorbs enough water. Later, they were placed on the ground, this has to be flat, dry and outdoors in a place (Figure 3c) where they received direct sunlight and plenty of air to dry completely during 1 to two months approximately. Then the pieces are transported to use them (Figure 3d).

The adobe constructions must comply with several important aspects of construction, such as low cost, safety to live, comfort and, at the same time, must be sustainable. Fortunately, historical monuments and heritage conservation have also been important to them, for that reason there have been several works to study forms to know their structural and superficial health.
Because their ancient value these buildings or monuments, in some cases, cannot be used in destructive or invasive tests so many non-destructive test systems have been developed as well as described by García-Diego (2012).

The study of ancient materials and technic is opportune to validate their mechanical properties and determine how convenient it is to build with them (GarcíaDiego, 2012). In the field of construction, several studies have been carried out to try to identify the mechanical properties of adobe masonry and its structural behavior within contractions and. Adobe is a block made of earth and natural fiber and has been part of the construction since 1500 and 1000 BC in China and became popular in 206-220 AD. C. Today, it is used in countries such as China, India, Turkey, Mexico, etc. (Wu et al., 2012). Invasive and destructive tests have been applied to this material with good results, which allows to determine the capacity of resistance, rigidity and deformation when the load increases, as explained in Silveira et al. (2012) and Lima et al. (2012).

However, there are buildings that cannot be exposed to regular breaks, due to their low resistivity, are impossible to transfer to a laboratory or only because of their historical value should not be touched (Kržan et al., 2015). These are reasons to perform nondestructive tests (NDTs). The NDT methods are non-invasive and have been used for approximately forty years in the structural analysis of civil engineering and the determination of material mechanical properties. In this case, ultrasonic systems have been one of the best ways to study the properties of materials without damaging buildings (Niederleithinger et al., 2015). Concrete is usually examined with destructive tests, but ultrasonic testing has also been used to measure the elastic properties of the concrete and assess degradation without damage, as shown in Niederleithinger et al., 2015.

Lately, a new growing interest in adobe masonry has been noticed as an environmentally friendly building material (Laborel-Préneron et al., 2016).
GUTIÉRREZ-VILLALOBOS, José Marcelino, MORENOMARTÍNEZ, Jatziri Yunuén, CATALÁN-QUIROZ, Policarpo and GALVÁN-CHÁVEZ Arturo. Characterization of adobe bricks used in developing countries: Mexico as a case of study. Journal of Architecture and Design. 2021 
Main problems are found in using this material are how to carry out the conservation works of historical buildings, usually adobe masonry and rammed earth, as well as the lack of skilled people to produce adobe, from designer to masons, because it is a forgotten technique. Hence, in recent years some recent investigations about adobe mechanical properties and characterization of adobe bricks, including earth blocks, have been performed for some authors: Morel et al. (2007) described methodologies used to determine compressive strength of compressed earth blocks, including direct testing, the RILEM test and indirect flexural strength testing. In addition, the influence of block geometry (aspect ratio), test procedure and basic material parameters (dry density, cement content, moisture content) are also discussed.

Quagliarini and Lenci (2010) investigated the changes in the mechanical properties of ancient roman adobe earthen bricks by varying the percentage of an on-situ soil, straw and coarse sand into the mixture to produce those bricks. Comparisons were also taken with samples made of only soil. Later, Quagliarini et al. (2010) developed an experimental research, in order to characterize the mechanical behavior of adobe walls.

On the other hand, NDT methods have been used for determining the mechanical properties of materials. Some ultrasonic wave works have also been accomplished to measure steel thickness, connecting a wireless sensor network, which makes it for multiple measurement point technique such as explained in Kouche and Hassanein (2012), ultrasonic methods can be combine with other nondestructive techniques, where X-Ray, thermography and vibration systems are mentioned by Jolly et al. (2015). Special configuration is certainly required for some ultrasonic systems, for example there are tests that require material piece immersion, a setup such as those is presented for Kappatosa et al. (2017). Finally, a very important aspects to consider in some cases, is adobe piece porosity, permeability, the mortar or cement radio and water content. Thus, cement and adobe are very similar as well. Fiber, soil and water are needed to prepare adobe mixture, which leads to different porosity levels and permeability as said by Lafhaj et al. (2006).

\section{Destructive tests}

Due to the inexistence of recommendations directed to adobe constructions in codes, some destructive tests have been carried out for determining mechanical properties (Aubert et $a l ., 2013$ ) and the structural response of adobe bricks under loading (Illampas et al., 2013) of adobe masonry: in Silveira et al. (2012) a study about the mechanical properties of adobe bricks collected form houses and land dividing walls in Aveiro district, Portugal, representative of existing traditional buildings, was performed. Some (lab-based) experimental tests were performed including cylindrical adobe specimens, which were subjected to simple compression and splitting tests.

Therefore, it was possible to evaluate, using cylinders: the stiffness, strength capacity and deformation evolution for increasing loading. Later, Silveira et al. (2013) performed a study related to the influence of testing procedures in the mechanical characterization of adobe bricks traditionally used in Aveiro district, Portugal. Cylindrical and cubic adobe specimens were subjected to simple destructive tests (compression tests), adobe bricks to flexural tests, and cylindrical adobe specimens to splitting tests.

On the other hand, Turanli and Saritas (2011), using additives and plaster mesh in adobe wall panels, performed an experimental investigation by means of destructive tests. Ultimate load capacities, deformability, and energy absorption characteristics were evaluated. These authors concluded that, the combined use of plaster mesh with additives enhances the structural response significantly. Other authors have included fibers (Cassese, et al., 2021) in their studies about of adobe masonry using this type of tests, for evaluating the changes in the mechanical properties of this material: Yetgin et al. (2008) performed uniaxial compressive tests for five different adobe mixtures done with natural fiber mixtures. According to this study as fiber content increases, compressive and tensile strengths decrease, and shrinkage rates decrease. On the other hand, Piattoni et al. (2011) concluded that with the presence of the straw fibers, the final strain is the double in comparison with the strains corresponding to the maximum stress for all the compositions tested. 
Some authors (Piattoni et al., 2011; Vega et al., 2011; Millogo et al., 2014) have mentioned that traditional adobes with different fibers (straw and Hibiscus cannabinus fibers) can be used as an adequate construction material. Some fibers can increase of the mechanical properties due to the nonpropagation of cracks for the presence of these (Millogo et al., 2014).

Other materials or techniques (e.g. corn plant, bamboo particles or "synthetic termite saliva") used to improve the mechanical properties of adobe have been proposed for some authors (Ribeiro Corrêa et al., 2015; Serrano et al., 2016). As it is possible to observe there are many investigations, with traditional adobe or adobe considering fibers, that use lab-based experimental tests by means of destructive tests. However, seldom "in situ" investigations have been carried, e.g. in Adorni et al. (2013) an in situ mechanical characterization of 2000 years old adobe bricks from the archaeological site of Nisa Partica in Turkmenistan was performed. In thus study, a portable instrument was designed to perform three point bending, compression and 'Brazilian' tests. Hence, it is important to measure the mechanical properties of adobe bricks even in critical in situ conditions, because of this, NDT's are proposed. This type of tests has been used in some materials like concrete or steel. However, in adobe masonry they are not frequently used.

\section{Nondestructive tests (ultrasonic methods)}

In ultrasonic tests, high frequency sounds waves are employed, in the range between $500 \mathrm{~Hz}$ and $15 \mathrm{MHz}$. Ultrasound tests are based on the sense and quantification of sound waves transmitted and reflected pulses called echo. Those waves are dived into two groups, longitudinal waves and transverse waves (shear waves). These tests are classified in five different types and they are the most normally used (McCann and Forde, 2001; Hola and Schabowicz, 2010; Schabowicz, 2014). These methods are listed below:

Sonic transmission method. In this method, compressional wave transmission through the thickness of a structure using frequencies between $500 \mathrm{~Hz}$ and $50 \mathrm{kHz}$ is employed.

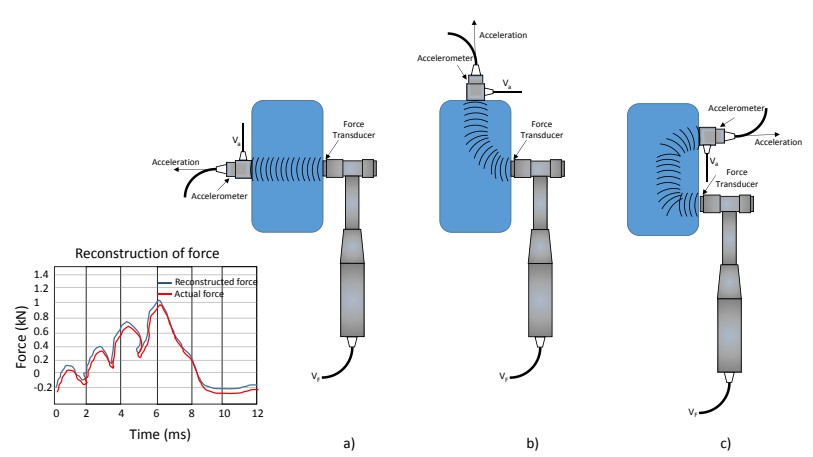

Figure 4 Ways of ultrasonic wave measurement (a) direct, (b) semidirect and c) indirect.

Self-Authorship

The wave transmission starts on one side of the wall, when the structure is hit by a force hammer and the reception of the wave is received by an accelerometer placed on the other side of the wall. This measurement can be performed in three different ways, as shown in Figure 4.

Sonic/seismic tomography. With this method, measurements are performed perpendicular to the surface of the wall or crossed by to have a set of readings, this group of structure values are related to measure specific times of ultrasonic wave travel, which are computed and with a series of iterations, structure mechanical properties can be estimated as it is observed in Figure 5.

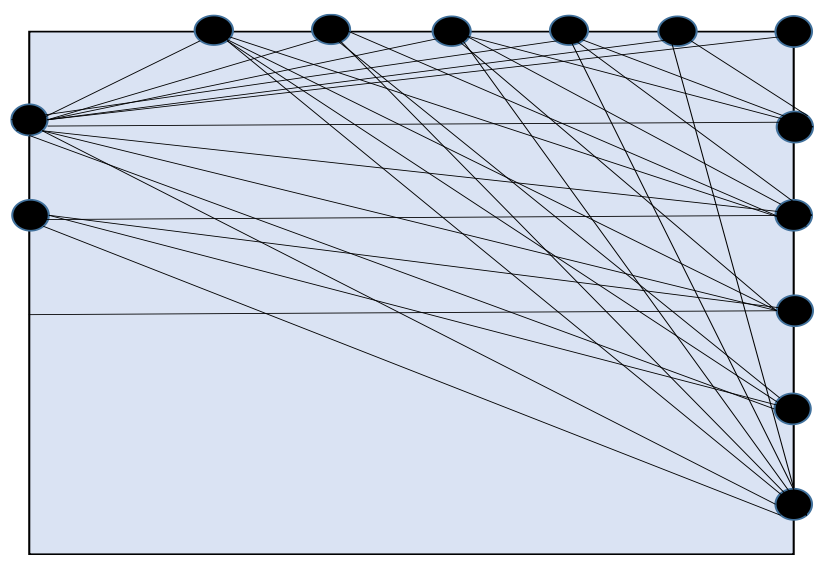

Figure 5 A structure is measured from different points and a set of several values is obtained Self-authorship

Sonic/seismic reflection method. According to this method. The beginning and the reception of ultrasonic waves start on the same side of masonry, which is the case for indirect transmissions, but the path that is travelled by the wave is the direct same path where the reflected wave passes back, so the time it takes to go and come has to be divide between two. 
In order to have only the time that sounds takes to go through the wall and calculate the material mechanical properties. The common frequencies used by the method are between $100 \mathrm{~Hz}$ and $1 \mathrm{kHz}$. Some problems, this method can have, are the dimensions and shape of the structure, cracks and voids within internal material structure and material surface, those issues can affect measurements.

Ultrasonic reflection method. In this case, the masonry structure thickness that can be measured is between 50 and $100 \mathrm{~mm}$. It can be used for the detection of cracks and flaws in metal pieces casting. This method is the main technique employed for NDTs in concrete. There is a need for coupling agents to connect ultrasonic sensors to the surface and it is alike to method mentioned before. Basically, it is the method used in this purposed work.

For this study about adobe masonry non-destructive tests, the method used for this research is based on the ultrasonic reflection method. This method consists of an ultrasound generating source and two piezoelectric transducers (Figure 6), one set as a transmitter and the other as a receiver. In this process, ultrasonic waves are generated by a transducer with operating frequencies above $20 \mathrm{kHz}$, this means wavelengths between $50-100 \mathrm{~mm}$ in adobe masonry as in Fortineau et al. (2017). In this research work, a transducer of $50 \mathrm{kHz}$, such as the one shown in Figure 6b, is used.

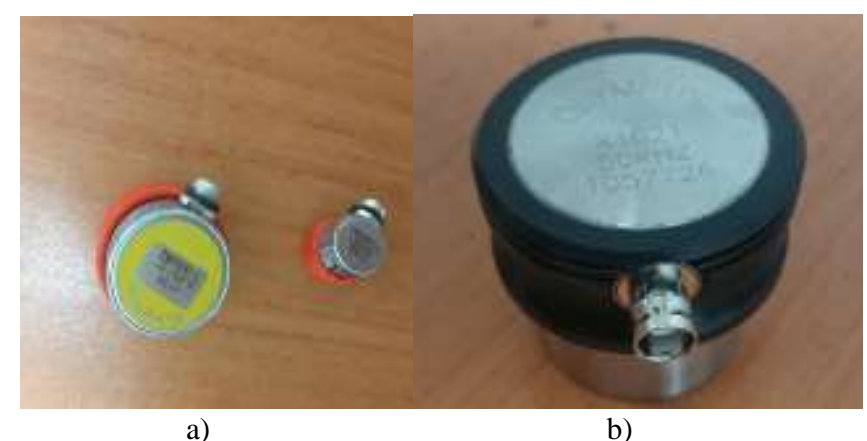

Figure 6 Piezoelectric transducers: a) transducers of $5000 \mathrm{kHz}$; b) transducer of $50 \mathrm{kHz}$ Self-authorship

\section{Experimental tests}

This section is divided in two parts. In the first part, destructive tests were carried out to obtain the elasticity modulus of adobe masonry used in the southeastern of Mexico.
The tested pieces were half-scale of typical adobe bricks built in this part of the country. Whilst, the second part consisted on using NDTs for the characterization of adobe masonry in this zone. Once the validation was performed, NDTs were used for the characterization of adobe bricks built central zone of Mexico. In this way, a comparison between two types of bricks were performed. It should be noted that for performing the destructive tests adobe pillars were built due to the complexity of testing a single adobe brick.

\section{Setup for Destructive tests}

In first place, to obtain adobe masonry mechanical properties, nine pillars, considering adobe masonry built in the southeastern of Mexico, were constructed to carry out axial tests, as shown in Figure 7. In this form, the elastic mechanical properties of adobe masonry from the southeastern of Mexico were obtained. The volumetric weight of the material was $13.24 \mathrm{kN} / \mathrm{m}^{3}$.

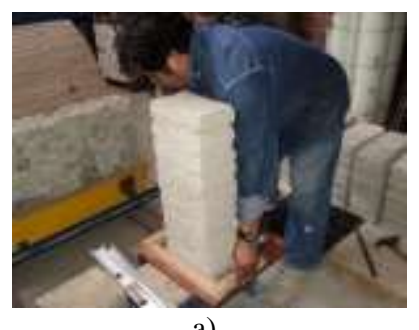

a)

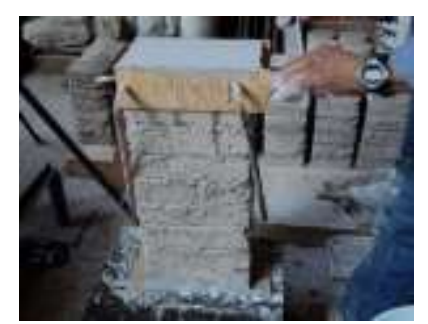

b)

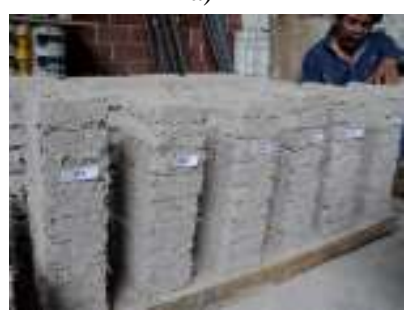

c)

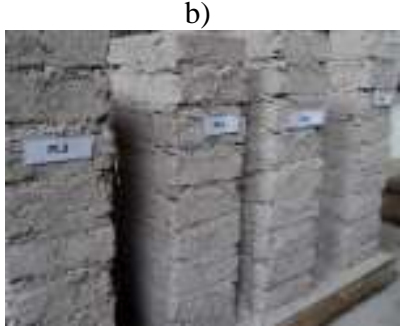

d)

Figure 7 Specimens built for compressive tests: a) construction of pillars; b) planar surface for performing a uniform stress distribution; c) storage of pillars; d) numbering of pillars

Self-authorship

The specimens were tested in a Universal Machine whose maximum load was 2,200 kN, approximately. Instrumentation was performed using Displacement Transducers (LVDTs), as presented in Figure 8, and a Data Acquisition System (DAS). Thus, by placing the transducers on the specimen, it was possible to accurately know the displacement in that direction for each load step. 


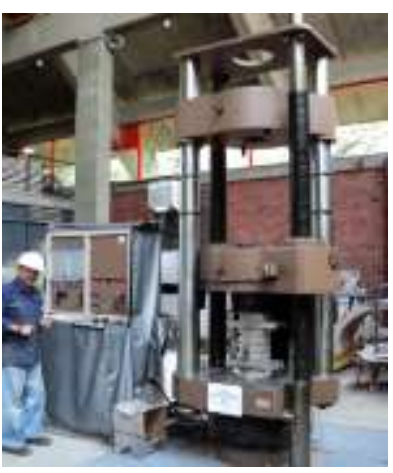

a)

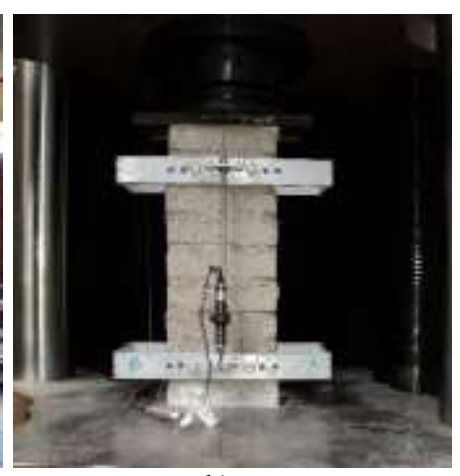

b)
Figure 8 Adobe masonry pillar: a) Testing; b) Instrumentation Self-authorship

The elasticity modulus $E_{m}$ was obtained according to Mexican Norm (equation 1):

$E_{m}=\frac{S_{2}-S_{1}}{e_{2}-0.00005}$

Where:

$S_{1}=$ Stress in $\mathrm{MPa}$ corresponding to strain $e_{1}=$ 0.00005

$S_{2}=$ Stress in MPa corresponding to $15-20 \%$ of maximum adobe masonry stress $e_{2}=$ Strain corresponding to $S_{2}$

From the measured elasticity in the specimens, average values were calculated (Table 1). The elasticity modulus $E_{m}$ was 240.94 MPa.

\begin{tabular}{|l|c|}
$\begin{array}{c}\text { Specimen } \\
\text { (Pillar) }\end{array}$ & \multicolumn{1}{c|}{$\begin{array}{c}\boldsymbol{E}_{\boldsymbol{m}} \\
(\mathbf{M P a})\end{array}$} \\
\hline Pillar-1 & 230.92 \\
\hline Pillar-2 & 219.24 \\
\hline Pillar-3 & 275.89 \\
\hline Pillar-4 & 210.86 \\
\hline Pillar-5 & 200.94 \\
\hline Pillar-6 & 197.64 \\
\hline Pillar-7 & 273.23 \\
\hline Pillar-8 & 317.67 \\
\hline Pillar-9 & 242.08 \\
\hline Average values & 240.94 \\
\hline
\end{tabular}

Table 1 Elasticity modulus $\left(E_{m}\right)$, one of the adobe masonry elastic mechanical properties from the southeastern of Mexico

\section{Setup for Non-Destructive test}

For this part, Non-destructive tests were made with individual pieces of adobe masonry built in southeastern of Mexico, instead of pillars. In this way, a validation between both type of test was performed. Once the validation was carried out, adobe bricks built in central zone of Mexico were tested using NDTs.
The electronic equipment used for this experiment was the Olympus EPOCH 650, which is a rugged flaw detector. So due to rough surface, it was a necessity to couple the piezoelectric transducers to the adobe masonry pieces with a coupling agent. Coupling agents such as oil, grease or ultrasound gel commonly used in pregnancy ultrasounds can be used. In order to adhere the transmitter and the receiver to the piece surface, ultrasound gel was employed. It is important to understand, that two velocities need to be measured in order to obtain the strength capacity, stiffness and deformation with Poisson's ratio and elasticity modulus respectively. Longitudinal velocity that occurs along the piece and transversal velocity which represent the shear velocity. This concept is explained in Figure 6. In the shear velocity measurement, transducers need to be in $45^{\circ}$ respect to the block surface with two wedges, they will be explained ahead, and this was well aimed in Hellier (2003).
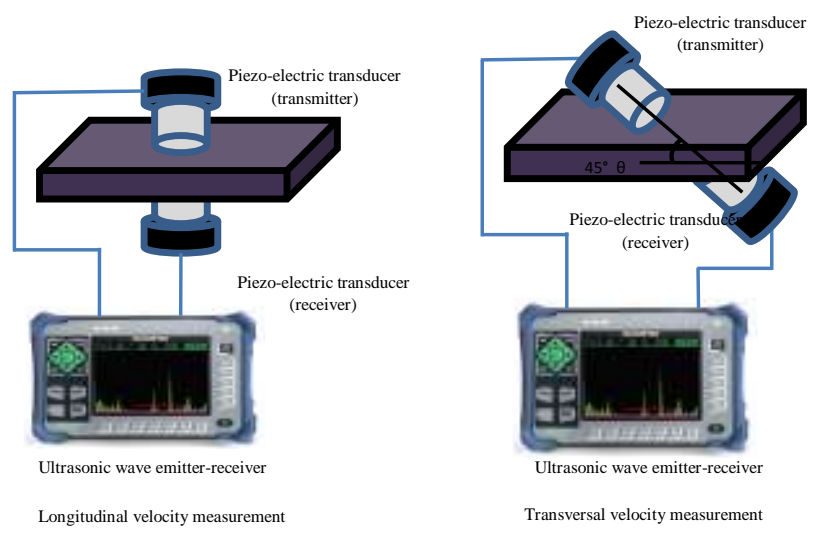

Figure 9 Setup for ultrasound velocity measurements Self-authorship

Longitudinal velocity $V_{L}$ and transversal one $V_{S}$ were estimated by equations described in the following part and measurement data obtained from the ultrasonic pulse emitterreceiver system. So, it is called that form because its main application, which is to measure time that sound takes inside materials to go through. These equations are described in Moore (2007). They have been used to measure other materials such as concrete in Chang (2014), where other equipment such as 5077PR was used. Velocity can be determined from equation (2).

$V=\frac{h}{t}$

Where:

$V=$ velocity

$h=$ Thickness

GUTIÉRREZ-VILLALOBOS, José Marcelino, MORENOMARTÍNEZ, Jatziri Yunuén, CATALÁN-QUIROZ, Policarpo and GALVÁN-CHÁVEZ, Arturo. Characterization of adobe bricks used in developing countries: Mexico as a case of study. Journal of Architecture and Design. 2021 


\section{$t=$ Trip transit time}

The units read on the instrument display were in inch/uS. Units had to be converted to $\mathrm{cm} / \mathrm{uS}$ and multiplied by $1 \times 10^{6}$ to be expressed in $\mathrm{cm} / \mathrm{S}$. starting from this Poisson's ratio $v$ can be calculated using (3).

$v=\frac{1-2 *\left(\frac{V_{T}}{V_{L}}\right)^{2}}{2-2 *\left(\frac{V_{T}}{V_{L}}\right)^{2}}$

Where:

$v=$ Poisson's ratio

$V_{T}=$ Shear (transversal) velocity

$V_{L}=$ Longitudinal velocity

Now to calculate elasticity modulus $E_{m}$, both velocities are necessary as well. This time density is included. Using equation (4).

$E_{m}=\frac{V_{L}^{2} \rho *(1+v) *(1-2 v)}{1-v}$

Where:

$V_{L}=$ Longitudinal velocity

$\rho=$ Density

$v=$ Poisson's ratio

\section{Validation and comparison of tests}

NDTs were performed with Olympus EPOCH 650 system on adobe masonry. These tests took place in the Material Laboratory at the University of Guanajuato where five pieces (ten in total) of two different adobe bricks from different origin places were tested. Different construction forms were used to make those bricks. The first block is from the southeastern of Mexico (1:2 scaled-down adobe pieces), the second block is from the central part of the country (full scale adobe bricks).

Even though, they were almost the same material and they were made following the same procedure, they presented some differences such as type of fiber and water level during mixing but in spite of that, their mechanical properties stayed alike. The two bricks are shown in Figure 7. Their physical properties are listed in Table 2.

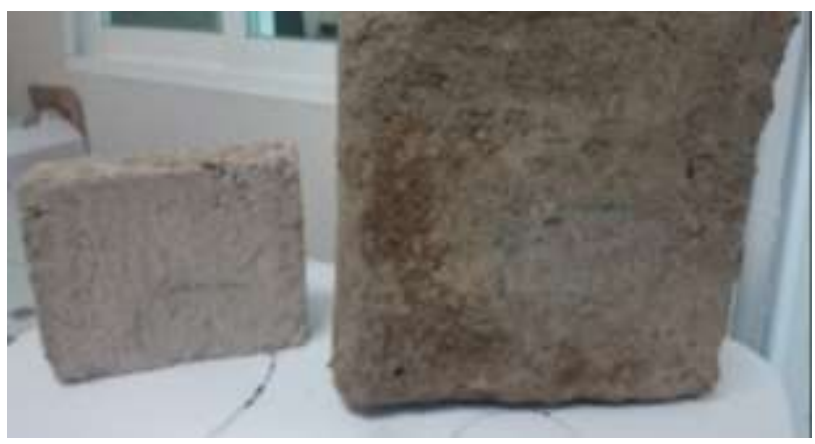

Figure 10 Adobe bricks from the southeastern of Mexico (half scale) and from central part of the country (full scale)

Self-authorship

\begin{tabular}{|l|r|r|}
\multicolumn{1}{|c}{$\begin{array}{c}\text { Physical } \\
\text { properties }\end{array}$} & \multicolumn{1}{c}{$\begin{array}{c}\text { Brick from } \\
\text { southeastern of } \\
\text { Mexico } \\
\text { (half scale) }\end{array}$} & $\begin{array}{c}\text { Brick from central } \\
\text { part of Mexico } \\
\text { (full scale) }\end{array}$ \\
\hline $\begin{array}{l}\text { Dimensions } \\
(\mathrm{cm})\end{array}$ & $21.5 \times 5.3 \times 14.5$ & $30.5 \times 7 \times 26.5$ \\
\hline $\begin{array}{l}\text { Mass } \\
(\mathrm{kg})\end{array}$ & 2.175 & 7.425 \\
\hline $\begin{array}{l}\text { Volume } \\
\left(\mathrm{cm}^{3}\right)\end{array}$ & 1652.27 & 5657.75 \\
\hline $\begin{array}{l}\text { Density } \\
\left(\mathrm{kN} / \mathrm{m}^{3}\right)\end{array}$ & 13.16 & \\
\hline
\end{tabular}

Table 2 Physical properties of typical adobe masonry bricks used in Mexico

Besides the EPOCH 650, two $50 \mathrm{kHz}$ ultrasonic transducers were needed to performance the measurements, these transducers are suitable to work with this kind of materials such as concrete, brick and inconsistent materials. Measurements were done on a fixed surface to avoid vibrations or natural disturbances and not to affect instrument readings. For transversal velocity measurement is necessary to use the 2 plastic wedges. Transducers and wedges are shown in Figure 11.

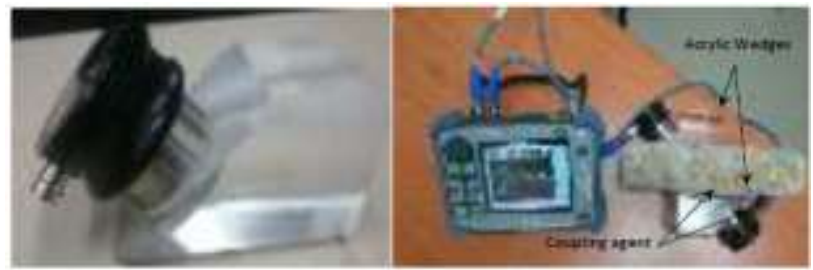

a)

b)

Figure 11 Measurement: a) $50 \mathrm{kHz}$ transducer with plastic wedge; b) Setup for the brick from central part of Mexico

Self-authorship 
Ultrasound pulse measurement were conducted using equations from (1) to (4), the setup for tests is presented in Figure 6. In this figure, a test performed on one of the pieces is shown. The $45^{\circ}$ collation and coupling agent between the wedges and the piece. Another important thing is that sensor should be coupled with the same agent to the wedges otherwise signal can be attenuated.

Results of two pieces are reported in Table 3 and Table 4, the first piece from southeastern and the second one from central part of the country, respectively. Where the Poisson's ratio and elasticity modulus are listed and the density for both blocks is presented. The densities obtained in these two pieces, besides of being very similar, are close to values that were determined from destructives tests and other adobe pieces take from the same set of pieces.

\begin{tabular}{|c|c|c|c|c|}
\hline $\begin{array}{c}T_{L} \\
(\mathbf{u S})\end{array}$ & $\begin{array}{c}V_{L} \\
(\mathbf{i n} / \mathbf{u S})\end{array}$ & $\begin{array}{c}V_{L} \\
(\mathrm{~cm} / \mathrm{S})\end{array}$ & $\begin{array}{c}\text { Poisson's ratio } \\
v\end{array}$ & $\begin{array}{c}\text { Elasticity } \\
\text { Modulus } \\
E_{m} \\
(\mathrm{MPa})\end{array}$ \\
\hline 106.1 & 0.01885 & 47879.359 & 0.44 & 221.879 \\
\hline$T_{T}(\mathrm{uS})$ & $V_{T}(\mathrm{in} / \mathrm{uS})$ & $V_{T}(\mathrm{~cm} / \mathrm{S})$ & & \\
\hline 185.3 & 15218.565 & 38655.154 & & \\
\hline
\end{tabular}

$T=$ sound flying time, $L=$ longitudinal, $T=$ transversal.

Table 3 Mechanical properties of southeastern adobe masonry brick

\begin{tabular}{|c|c|c|c|c|}
\hline $\begin{array}{c}\boldsymbol{T}_{\boldsymbol{L}} \\
(\mathbf{u S})\end{array}$ & $\begin{array}{c}\boldsymbol{V}_{\boldsymbol{L}} \\
(\mathbf{i n} / \mathbf{u S})\end{array}$ & $\begin{array}{c}\boldsymbol{V}_{\boldsymbol{L}} \\
(\mathbf{c m} / \mathbf{S})\end{array}$ & $\begin{array}{c}\text { Poisson's ratio } \\
\boldsymbol{v}\end{array}$ & $\begin{array}{c}\text { Elasticity } \\
\text { Modulus } \\
\boldsymbol{E}_{\boldsymbol{m}} \\
(\mathbf{M P a})\end{array}$ \\
\hline 157.2 & 0.01908 & 48473.282 & 0.43 & 227.385 \\
\hline$T_{T}(\mathrm{uS})$ & $V_{T}(\mathrm{in} / \mathrm{uS})$ & $V_{T}(\mathrm{~cm} / \mathrm{S})$ & & \\
\hline 275.1 & 0.01540 & 39119.506 & & \\
\hline
\end{tabular}

$T=$ sound flying time, $L=$ longitudinal, $T=$ transversal.

Table 4 Mechanical properties of adobe masonry brick obtained from central part of the country

A comparison between experimental results obtained from two types of tests was performed (Table 5).

\begin{tabular}{|c|c|c|c|}
\hline Specimen & $\begin{array}{l}\text { Density } \\
\left(\mathrm{kN} / \mathrm{m}^{3}\right)\end{array}$ & $\begin{array}{c}\text { Type of } \\
\text { test }\end{array}$ & $\begin{array}{c}E_{m} \\
(\mathrm{MPa})\end{array}$ \\
\hline $\begin{array}{ll}\text { Southeastern } & \text { adobe } \\
\text { masonry brick } & \end{array}$ & 13.16 & NDT test & 226.54 \\
\hline $\begin{array}{l}\text { Central part adobe masonry } \\
\text { brick }\end{array}$ & 13.12 & & 231.01 \\
\hline $\begin{array}{ll}\text { Southeastern } & \text { adobe } \\
\text { masonry brick } & \end{array}$ & 13.24 & $\begin{array}{l}\text { Destructive } \\
\text { test }\end{array}$ & 240.94 \\
\hline
\end{tabular}

Table 5 Elasticity modulus of adobe bricks $\left(E_{m}\right)$
From values obtained, it is clear that results from NDTs and destructive tests are similar $(6 \%$ of difference between both tests for the obtention of the elasticity modulus), it is possible to calculate adobe masonry mechanical properties with both methods with close values. As well as, Poison's ratio and the elasticity modulus were closed in both types of adobe brick, 0.44 and 0.43 for southeastern and central part adobe masonry brick, respectively. Thus, the mixture (earth combined with straw and water) obtained to build adobe masonry bricks in these two parts of Mexico produces the same rigidity of this material.

\section{Conclusions}

Mechanical properties of adobe masonry can be obtained using destructive tests in pillars or cylinders (for obtaining elasticity modulus, Poisson's ratio and tensile and compressive strength) due to the complexity of testing a single brick. However, in some cases, destructive tests are not possible to apply for obtaining these properties. Such is the case of historical buildings, e.g. constructions carried out with adobe masonry. Thus, NDTs can be performed for rescuing the heritage of this type of constructions. The NDT system and the method used in this study to estimate the adobe masonry elastic mechanical properties showed good results compared to destructive tests, the elasticity modulus obtained was closed in both methods (6\% of difference between both tests), which validates the alternative method proposed in this research. In addition, these NDTs can be used "in situ" to measure the elastic mechanical properties (elasticity modulus and Poisson's ratio) of adobe bricks even in critical conditions.

It should be noticed that both types of brick coming from different parts of Mexico (southeastern and central part of the country) present approximately the same elastic mechanical properties because of their construction process that is very similar in these two parts of the country. There no précised values about adobe Poisson's ratio and elasticity modulus, but according to this method in compare to the destructive one and other data obtained in other works, it is concluded that this NDT technique is suitable for the analysis of adobe pieces and structures. 


\section{Acknowledgments}

The authors acknowledge the financial support of the project "Convocatoria Institucional de Investigación 2016-2017 (Clave: 947/20162017) Universidad de Guanajuato". Authors also recognize the technical support received by the whole staff of the Structural Laboratory of the Instituto de Ingeniería, UNAM.

\section{References}

Adorni E, Coïsson E and Ferretti D (2013) In situ characterization of archaeological adobe bricks, Constr. Build. Mater. 40 (2013) pp 1-9, https://www.sciencedirect.com/science/article/p ii/S095006181200815X.

Arroyo Matus R (2010) The adobe housing of Guerrero, geometric characteristics and study of environmental vibration, Universidad Autónoma de Guerrero, México, 2010 [in Spanish].

Aubert JE, Fabbri A, Morel J C, Millard P. (2013) An earth block with a compressive strength higher than $45 \mathrm{MPa}$ !, Constr. Build. Mater. Vol. 47 (2013) pp 366-369, http://dx.doi.org/10.1016/j.conbuildmat.2013.0 5.068 .

Bassoud, A., Khelafi, H., Mokhtari, A. M., \& Bada, A. (2021). Effectiveness of Salty Sand in Improving the Adobe's Thermomechanical Properties: Adrar Case Study (South Algeria). Trends in Sciences, 18(19), 6-6.

Cassese, P., Balestrieri, C., Fenu, L., Asprone, D., \& Parisi, F. (2021). In-plane shear behavior of adobe masonry wallets strengthened with textile reinforced mortar. Construction and Building Materials, 306, 124832.

Chang CH, Her I and Shih TS (2014) A simplified UTV hand tool featuring $2.25 \mathrm{MHz}$ transducers to measure the BMD of calcaneus - tested on acrylic blocks padded with fresh porcine tissue, Measurement, Vol. 47 (2014) pp 765-769, http://www.sciencedirect.com/science/article/pi i/S0263224113004673.

Consejo Nacional de Evaluación de la Política de Desarrollo Social CONEVAL (2015), Dirección de información y comunicación social, Comunicado de Prensa No.005, 23 de Julio de 2015. México, DF [in Spanish].

ISSN 2531-2162

ECORFAN® All rights reserved
De Filippi, F., Pennacchio, R., Torres, S., \& Restuccia, L. (2021). Anti-Seismic Retrofitting Techniques for Vernacular Adobe Buildings in Colombia: A Proposed Framework for Developing and Assessing Sustainable and Appropriate Interventions. International Journal of Architectural Heritage, 1-17.

Fortineau JP, Meulena FV, Fortineau $\mathrm{J}$ and Feuillard G (2017) Efficient algorithm for discrimination of overlapping ultrasonic echoes, Ultrasonics, Vol. 73 (2017), pp 253261,

http://www.sciencedirect.com/science/article/pi i/S0041624X16301901.

García-Diego FJ, Bravo JM, Pérez-Miralles J, Estrada H and Fernández-Navajas A (2012) Development of a Low-Cost Airborne Ultrasound Sensor for the Detection of Brick Joints behind a Wall Painting, Sensors 2012, 12 ,

1299-1311; https://www.ncbi.nlm.nih.gov/pubmed/2243871 1.

Hellier CJ, Allgaier MW, Drury J, Finlayson RD, Harrison RA, Pond RB, Jr., Quinn GR, Shakinovsky M, Snell JR, Jr. and Robert W (2003) Spring, Handbook of Nondestructive Evaluation, First Edition, (2003), pp 7.9-7.18.

Hoła J and Schabowicz K (2010) State-of-theart non-destructive methods for diagnostic testing of building structures - anticipated development trends, Archives Of Civil And Mechanical Engineering, Vol. 10, Issue 3, (2010), pp. 5-18, http://www.sciencedirect.com/science/article/pi i/S1644966512601332.

Illampas R, Ioannou I and Charmpis DC (2014) Adobe bricks under compression: Experimental investigation and derivation of stress-strain equation, Constr. Build. Mater. 53 (2014) 8390 ,

http://dx.doi.org/10.1016/j.conbuildmat.2013.1 1.103.

Jolly MR, Prabhakar A, Sturzu B, Hollstein K and Singh R (2015) Thomas S., Foote P., A. Shaw, Review of Non-destructive Testing (NDT) Techniques and their applicability to thick walled composites, Procedia CIRP, Vol. 38 (2015) pp 129-136, http://www.sciencedirect.com/science/article/pi i/S2212827115008021.

GUTIÉRREZ-VILLALOBOS, José Marcelino, MORENOMARTÍNEZ, Jatziri Yunuén, CATALÁN-QUIROZ, Policarpo and GALVÁN-CHÁVEZ, Arturo. Characterization of adobe bricks used in developing countries: Mexico as a case of study. Journal of Architecture and Design. 2021 
Kappatos V, Asfisb G, Salonitisc K, Tzitzilonis $\mathrm{V}$, Avdelidise NP, Cheilakouf $\mathrm{E}$ and Theodorakeas P (2017) Theoretical Assessment of Different Ultrasonic Configurations for Delamination Defects Detection in Composite Components, Procedia CIRP, Vol. 59, (2017), pp. 29-34, http://www.sciencedirect.com/science/article/pi i/S2212827116311179.

Kouche AE and Hassanein HS (2012) Ultrasonic Non-Destructive Testing (NDT) Using Wireless Sensor, Procedia Computer Science, Vol. 10, (2012), pp 136-143, http://www.sciencedirect.com/science/article/pi i/S187705091200378X.

Kržan M, Gostič S, Cattari S and Bosiljkov V (2015) Acquiring reference parameters of masonry for the structural performance analysis of historical buildings, Bulletin of Earthquake Engineering, Vol. 13 (2015) pp 203-236, https://link.springer.com/article/10.1007/s1051 8-014-9686-x.

Laborel-Préneron A, Aubert JE, Magniont C, Tribout C and Bertron A (2016) Plant aggregates and fibers in earth construction materials: A review, Constr. Build. Mater. Vol 111 (2016) pp 719-734, http://dx.doi.org/10.1016/j.conbuildmat.2016.0 2.119 .

Lafhaj Z, Goueygou M, Djerbi A and Kaczmarek M (2006) Correlation between porosity, permeability and ultrasonic parameters of mortar with variable water / cement ratio and water content, Cement and Concrete Research, Vol. 36, (2006), pp. 625633,

http://www.sciencedirect.com/science/article/pi i/S0008884605002760.

Lima SA, Varum H, Sales A, Neto VF (2012) Analysis of the mechanical properties of compressed earth block masonry using the sugarcane bagasse ash, Vol. 35 (2012) pp 829837 ,

http://www.sciencedirect.com/science/article/pi i/S0950061812003315.
Ma HW, Zhang XH and Wei J (2002) Research on an ultrasonic NDT system for complex surface parts, Journal of Materials Processing Technology. Vol. 129 (2002) pp 667-670, http://www.sciencedirect.com/science/article/pi i/S0924013602006787.

McCann DM and Forde MC (2001) Review of NDT methods in the assessment of concrete and masonry structures, NDT \& E International. Vol. 34 (2001), pp 71-84, http://www.sciencedirect.com/science/article/pi i/S0963869500000323.

Millogo Y, Morel JC, Aubert JE and Ghavami $\mathrm{K}$ (2014) Experimental analysis of Pressed Adobe Blocks reinforced with Hibiscus cannabinus fibers, Constr. Build. Mater. Vol. 52 (2014) 71-78, http://dx.doi.org/10.1016/j.conbuildmat.2013.1 0.094 .

Moore P (ed.) (2007), Nondestructive Testing Handbook, Vol 7, American Society for Nondestructive Testing, 2007, pp. 319-321.

Morel JC, Pkla A and Walker P (2007) Compressive strength testing of compressed earth blocks, Constr. Build. Mater. Vol. 21 (2007) pp 303-309, http://doi.org/10.1016/j.conbuildmat.2005.08.0 21.

Niederleithinger E, Wolf J, Mielentz F, Wiggenhauser $\mathrm{H}$ and Pirskawetz S (2015) Embedded Ultrasonic Transducers for Active and Passive Concrete Monitoring, Sensors, 2015, Vol. 15 (2015), pp. 9756-9772, https://www.ncbi.nlm.nih.gov/pmc/articles/PM C4481983/pdf/sensors-15-09756.pdf.

Piattoni Q, Quagliarini E and Lenci S (2011), Experimental analysis and modelling of the mechanical behaviour of earthen bricks, Constr. Build. Mater. Vol. 25 (2011) 2067-2075, http://dx.doi.org/10.1016/j.conbuildmat.2010.1 1.039 .

Quagliarini E and Lenci S (2010) The influence of natural stabilizers and natural fibres on the mechanical properties of ancient Roman adobe bricks, J. Cult. Herit. Vol. 11 (2010) pp 309314 ,

http://dx.doi.org/10.1016/j.culher.2009.11.012. 
Quagliarini E, Lenci S and Iorio M (2010) Mechanical properties of adobe walls in a Roman Republican domus at Sausa, J. Cult. Herit. Vol. 11 (2010) pp 130-137, http://doi.org/10.1016/j.culher.2009.01.006.

Ribeiro Corrêa AA, Marin Mendes L, Perazzo Barbosa N, de Paula Protásio T, de Aguilar Campos N, Denzin Tonoli GH (2015) Incorporation of bamboo particles and "synthetic termite saliva" in adobes, Constr. Build. Mater. Vol. 98 (2015) 250-256, http://dx.doi.org/10.1016/j.conbuildmat.2015.0 6.009 .

Salazar-Hernández, C., Puy-Alquiza, M. J., Miranda-Avilés, R., Salazar-Hernández, M., Mendoza-Miranda, J. M., Mocada-Sánchez, C. D., \& del Ángel-Soto, J. (2021). Comparative study of TEOS-consolidants for adobe building conservation. Journal of Sol-Gel Science and Technology, 97(3), 685-696.

Schabowicz K (2014) Ultrasonic tomography The latest nondestructive technique for testing concrete members - Description, test methodology, application example, Archives of Civil and Mechanical Engineering, Vol. 14, Issue 2, (2014), pp. 295-303, http://www.sciencedirect.com/science/article/pi i/S1644966513001374.

Serrano M, Blondet M, Rubiños A, Mattsson E. (2016) Sustainable dissemination of earthquake resistant construction in the Peruvian Andes, Sustainability: Science, Practice, \& Policy, Vol. 12 (2016) pp 1-12.

Silveira D, Varum H, Costa A, Martins T, Pereira H and Almeida J (2012) Mechanical properties of adobe bricks in ancient constructions, Construction and Building Materials. Vol. 28 (2012) pp 36-44, http://www.sciencedirect.com/science/article/pi i/S095006181100479X.

Silveira D, Varum H, Costa A (2013) Influence of the testing procedures in the mechanical characterization of adobe bricks, Constr. Build. Mater. Vol. 40 (2013) pp 719-728, http://dx.doi.org/10.1016/j.conbuildmat.2012.1 1.058 .
Turanli L and Saritas A (2011) Strengthening the structural behavior of adobe walls through the use of plaster reinforcement mesh, Constr. Build. Mater. Vol. 25 (2011) pp 1747-1752, http://dx.doi.org/10.1016/j.conbuildmat.2010.1 1.092 .

Wu F, Li G, Li HN and Jia JQ (2013) Strength and stress-strain characteristics of traditional adobe block and masonry, Materials and Structures, Vol. 46 (2013) pp 1449-1457, https://link.springer.com/article/10.1617/s1152 7-012-9987-y.

Vega P, Juan A, Guerra MI, Morán JM, Aguado PJ and Llamas B (2011) Mechanical characterisation of traditional adobes from the north of Spain, Constr. Build. Mater. Vol. 25 (2011) 3020-3023, http://doi.org/10.1016/j.conbuildmat.2011.02.0 03.

Yetgin S, Çavdar Ö and Çavdar A (2008) The effects of the fiber contents on the mechanic properties of the adobes, Constr. Build. Mater. Vol. $22 \quad$ (2008) 222-227, http://dx.doi.org/10.1016/j.conbuildmat.2006.0 8.022 .
GUTIÉRREZ-VILLALOBOS, José Marcelino, MORENOMARTÍNEZ, Jatziri Yunuén, CATALÁN-QUIROZ, Policarpo and GALVÁN-CHÁVEZ Arturo Characterization of adobe bricks used in developing countries: Mexico as a case of study. Journal of Architecture and Design. 2021 